\title{
PALM OIL INDUSTRY: CERTIFICATION DEVELOPMENT
}

\author{
Sean Andrew Labansing ${ }^{1}$, Yeo Soon Jian ${ }^{2}$, Tang Chung Siong ${ }^{3}$, Tracy Joann Stanlee ${ }^{4}$
}

Faculty of Business, Economics and Accountancy

Faculty of Psychology and Education

Universiti Malaysia Sabah

*Corresponding author: alsean@gmail.com

\begin{abstract}
The agricultural industry has been the backbone of Sabah's economy for decades. The industry has eradicated poverty and supported connectivity between the rural with the urban area. At the same time, it has undergone numerous shifts of cash crops to sustain the economy with the oil palm as the latest crop. The palm oil industry has both novelty and challenges to thrive with the demand for sustainability. For the mandatory certification of Malaysia Sustainable Palm Oil, growers, mainly smallholders, faced restrictions on the certification process despite incentives from the federal government. This has put a setback to the effort by the palm oil industry in their commitment to being sustainable. In this study, the researchers plan to examine the palm oil industry's certification approach on the smallholders on their way to achieving a sustainable palm oil industry based on a case study approach. Therefore, the methodology for the study was using content analysis on public-domain literature found through electronic databases encompasses publications dating from 2000 to 2020. The study found that the acceptance and trust in smallholders' certification process are in correspond with the incomprehension and the certification process approach.
\end{abstract}

Key Words: Sustainability, Acceptance, Trust, Malaysia Sustainable Palm Oil, Smallholders, Stakeholders.

\subsection{Introduction}

This paper aims to investigate and evaluate growers, mainly smallholders, towards Malaysia Sustainable Palm Oil (MSPO) certification and fill this gap in the literature. Demand for palm oil has risen in tandem with the world population's rapid growth projected to reach 9.7 billion by 2050 (UN, 2019). Over the past five years, global palm oil production has increased by nearly 17 per cent to nearly 70 million tons (Bakke, 2019). Moreover, supply was due to crop efficiency in a hectare of land compared to other vegetable oil (Umesha, Manukumar, \& Chandrasekhar, 2017). Various products of palm oil can be found in the supermarkets and as animal feed (RSPO, 2008).

The palm oil industry (POI) is one of the vital socio-economic drivers of Sabah. The POI expanded during a continuous fall in the price of rubber by replacing its rubber trees with oil palm trees (Pirker, Mosnier, Kraxner, Havlík, \& Obersteiner, 2016). Similarly, the POI has played a significant role in alleviating poverty among smallholders and the rural population of Sabah. Tengku, (2001) added that the incidence of poverty among smallholder was the lowest among all agricultural sub-sectors. Furthermore, the communities surrounding the POI 
benefited from the expansion of connectivity between rural and urban areas (Corley, 2018) with the upgraded infrastructure. However, smallholders are perceived to be inefficient and unproductive (Abdullah, 2013), producing barely half of the national average (Abazue, Er, Ferdous Alam, \& Begum, 2015) yields that have barely broken even in their returns/profits. Some smallholders, therefore, have financial constraints to participate in the certification process for MSPO. This has posed a further challenge to the POI in the sustainability process.

Sustainability in the POI has been discussed for a long time by Western NGOs, western consumers and food producers and the organisation that supplies them. The industry has been criticised for clearing the rainforest and destroying the orang-utan habitat, as well as for the conditions of the workforce and the threat to local communities from the appropriation of land by large firms (Greenpeace, 2015). MSPO certification has been established to enhance the sustainability of the industry further. Certification has been developed to reduce further deforestation and to establish plantations with improved agricultural practises (Mukherjee \& Sovacool, 2014). The certification process is thorough verification and certification by an independent third-party accredited Certification Body (CB) (Ang, 2017).

Certification's efficacy and sustainability targets depend on who is involved in the schemes. Most of the industry's significant growers (e.g. multi-national plantation firms) involved in certification are large plantation firms with the financial capacity to meet sustainability and certification goals (Lee, Rist, Obidzinski, Ghazoul, \& Koh, 2011). For smallholders, given government incentives, many still struggle to meet requirements, particularly in Sabah, as their primary concern is the cost of certification and market condition. Despite the mandatory MSPO certification by the end of 2019, as of 30 June 2019, there are less than 50 per cent of planted area are certified (Kok, 2019).

As far as sustainability is concerned, smallholders are positioned in the broader community and have the ability to manage the certification process for MSPO. Smallholders have the power to do so by taking advantage of their shared interests and values (Alexander, Andrachuk, \& Armitage, 2016) in their approach to the issue or activity. In order to retain their legitimacy, smallholders recognised the importance of maintaining their social obligations beyond their regulatory requirements. MSPO certification is not a prerequisite to a lawful operation but helps to gain legal approval in cases of legal or political ambiguity (Haward, Jabour, \& McDonald, 2013). Getting socio-legal recognition via MSPO certification gives the industry credibility for its activities (Ansell \& Gash, 2008).

Legitimacy referred to as the "minimum" requirement to obtain a social licence. Community acceptance and confidence provide higher rates of social licence (Parsons \& Moffat, 2014) and, most importantly, MSPO qualification (Ansell \& Gash, 2008). The collective power of smallholders "come to the table" can contribute to the success or failure of MSPO certification (Emerson, Nabatchi, \& Balogh, 2012). However, due to limited benefits, lack of common ground (Edelenbos \& van Meerkerk, 2018) and lack of trust, many smallholders cannot "go to the table" (Ansell \& Gash, 2008). Trust is an essential feature of partnership performance, enhances collaborative chances and promotes mutual ground growth (Edelenbos \& van Meerkerk, 2018). Nevertheless, a lack of trust can lead to MSPO certification failure first.

The fundamental argument for this paper is the smallholders' MSPO certification process. This paper examined how the implementation of the MSPO certification strategy and how smallholders embrace MSPO to obtain MSPO accredited for the POI. The focus of the study will be for smallholders in Sabah who face the challenges and are part of the smallholders in Malaysia who appeal to delay the MSPO certification deadline (Ling, 2019) until the market conditions improve (TheStar, 2019). 


\section{Literature Review}

\section{Certification for Sustainability}

For this paper, the researcher restricts the concept of sustainability to "Meeting the needs of the present without compromising the ability of future generations to meet their own needs"'(UNWCED, 1987: 43). Schepel, (2005) state that certification for sustainability (CS) means verging whether the business, product, service or management system is complied with by a pre-defined norm which may be enforced under the public law norm, a single standard or a combination of them. However, Rott, (2019) argued that CS as standardisation benefits primarily applicable stakeholders in the industries. Additionally, Schepel, (2005) added that CS could be biased to other purposes, such as customer protection or certain third parties. Jopke and Shconeveld, (2018) added that while some stakeholders are pressured to be sustainable, pressure has been ignored, and the situation remains the same. Hence, Schouten and Glasbergen, (2011) added that even by having CS, does not necessarily result in a sustainable commitment. Therefore, CS may be insufficient to tackle the problem of sustainability (Barry et al., 2012; Gallemore \& Jespersen, 2019).

\section{Stakeholder Theory}

Freeman defined the stakeholders as "any group or individual that materially impacts or affects the activities of the actor". Stakeholders can have a positive effect on the firm by investing means to produce or contribute value, benefits, wealth, or by providing support through their contribution or threatening, countering, harmful, damaging or hurting a company directly or by imposing a critical or mobilising opinion (Miles, 2017). Jones and Wicks, (1999) added that the essence of stakeholder theory is that all valid stakeholders' interests are of inherent value, and it is believed that there is no single dominant collection of interests. Where else, Donaldson and Preston, (1995) added that the theory explains how stakeholders attempt to influence the decision-making processes of the organisation to be following the needs and priorities and to seek to comprehend the interests of the different participants and to equalise them. Philips, (2003) added that in the stakeholder theory approach to sustainability certification, is to maximise business value creation based on relevant stakeholder interests, and fair allocation of business value to stakeholders. However, the certification influence on stakeholders can have an important implication for the power, legitimacy and urgency of actors, and by extension, industries (Aaltonen, Jaakko, \& Tuomas, 2008; Barry et al., 2012; Brandi, 2017; Olsen, 2017). Mitchell, Agle, and Wood, (1997) added that legitimacy is a social good, that it is higher and more universal than a mere self-perception, and that it can be described and negotiated differently at various levels of social organisation. Hence, Pfeffer and Salancik, (1978) added that actors should have social-value goals. Stakeholders are acting with limited information and, provided that the broader context allows freedom of choice, make decisions about whom to work or to associate (Harrison \& Wicks, 2019). Rowley, (2017) argue that the acts of stakeholders are triggered by motivations beyond rational self-interest alone and may act to seek social relations, trust and goodwill or simply to obey social norms or developed habits. This created a challenge for actors to manage resources, meet demand, select stakeholders to deliver (Vijayakumaran, Rahim, Ahmi, Rahman, \& Mazlan, 2020).

\section{Materials and Methods}

This analysis is focused solely on available data, such as reports from research literature and the palm oil industry. Analysed work on related palm oil certifications such as MSPO, 
Roundtable on Sustainable Palm Oil (RSPO) and Certified Sustainable Palm Oil (CSPO). The source is limited to Scopus, Jstor, Springer, Proquest and Science Direct, which is up-to-date using literature search and review from of 2000 to 2020. Since sustainability, stakeholders and value are interdisciplinary topics, and relevant articles get published in a wide variety of domains. An explanatory case study is used as an essential technique to seek to understand the suspected casual connexions in real-life interventions that are too nuanced for the survey or experimental approaches (Hancock \& Algozzine, 2006). Explanations in assessment language will connect programme execution to programme impact (Yin, 2018). In this paper, the researchers concentrate mainly on case studies, field studies and survey (empirical papers) excluding non-empirical papers. Keywords of MSPO, RSPO, sustainability, smallholders and stakeholder are the researchers' focus when conducting a content analysis using MAXQDA software as these are common to describe government agencies' approach to certification in the palm oil industry.

\section{Results and Discussion}

Smallholders face problems such as putting food on the table for their families, especially in times of uncertain palm oil prices that the palm oil industry is now experiencing (Albanya \& Er, 2018; Begum et al., 2018; Bek-Nielsen, 2019). Consequently, the primary concern of smallholders for MSPO is the "unjustifiable cost" of the certification process, since the cost is substantial for smallholders, in which, despite the recognition issued by foreign countries to the MSPO standard (Kok, 2019; Trade, 2019). Additionally, obtaining certification cannot guarantee a better price for smallholder palm fruit (Gianto, 2019; MIDF, 2019; Rahgu, 2019) but will protect their welfare to some extend (Albanya \& Er, 2018). Hence, Macdonald, (2020) argues that there has been significant concern regarding the exclusion of many smallholders from economic opportunities.

One aspect that emerged as a strong influence on MSPO certification acceptance is trust (Schaefer, Chen, Szalma, \& Hancock, 2016). Understanding what contributes to trust in certification and how it relates to acceptance is particularly critical, given the role that trust plays in the use and misuse of certification processes (Parasuraman \& Riley, 1997). Meijaard and Sheil, (2019) stated that credible information is essential as Muir, (1994) argues that certification can be excessively reliable, used in other unintended ways, or not used. Empirical results show that despite attending MSPO briefing, the smallholders' yield productivity has not increased (Albanya \& Er, 2018). The soaring price of fertiliser may contribute to the yield productivity as smallholders prompted to withdraw fertiliser usage as a measure to break even (Zulhusni, Nordin, \& Ahmad, 2017).

Acceptance and trust of smallholders are common elements that stand in the way of successful MSPO certification. Part of the reasons for this is that smallholders cultivated land granted to them under the Sabah Land Ordinance of 1930, but due to the political complexities surrounding land use and land management, there was an increase in tenure insecurity (Macdonald \& Balaton-Chrimes, 2016). Empirical results support this (Azima, Choy, \& Lyndon, 2018) and therefore, smallholders feared that if they continue with the MSPO certification process, they could lose their ground. The other aspect is the current consumer acceptance of MSPO certified palm oil, which has yet to show a sign of premium quality to palm fruits of growers.

Secondly, due to arm's length relationships with mills, reliance on intermediaries and collection centres, even smallholders possessing MSPO certification did not benefit from any premium 
price on their palm fruits. In this context, smallholders are committed to preserving the status quo/wait-and-see approach as it will depend heavily on the next move of the government (Macdonald \& Balaton-Chrimes, 2016). Some of the smallholders feel that something else is less important as long as there are buyers not concerned with MSPO certification (Bernama, 2019). Smallholders are therefore likely to resist the efforts of government agencies to convince them of the MSPO certification process. Certification may, however, be obtained through mutual trust and support. However, this may take time to establish - even if the necessary steps are taken to acquire the trust (Vince \& Haward, 2017).

While a myriad of smallholder compliance initiatives can affect whether MSPO certification does not reach its goals due to various institutional deficiencies, oil palm markets are expected to grow ever more bifurcated, and many smallholders remain locked into unsustainable and opaque supply chains that provide little incentive and resources for upgrading (Hidayat, Offermans, \& Glasbergen, 2018). Such obstacles undermine the government's concerted efforts to improve reputation and international recognition of MSPO certification.

\section{Conclusion}

In Malaysia's POI, MSPO certification was implemented as credible sustainability to enhance social, economic and environmental impact. MSPO certification has its benefits and disadvantages based on factors in contrast. MSPO certification tackles oil palm production by implementing best practises for current planting and replanting. The POI is also quite competitive, and certification is seen as a currently prevailing to illustrate compliance with an agreed certification standard's good practises and criteria (Kumaran, 2018). As such, the MSPO certification will be subject to periodic revisions to ensure that the criteria and thresholds specified in the standards not only meet but exceed stakeholder expectations through a comprehensive, participatory involvement process (Kuntom \& Carotino, 2014).

Sustainability experiences in many study areas, particularly in the MSPO, RSPO and CSPO certification process, highlight the opportunities and challenges of sustainable palm oil certification (Ang, 2017; Chin, 2019; Kumaran, 2018). In this study, acceptance and trust in smallholders' certification process are in correspond with Pacheco, Gnych, Dermawan, Komarudin, and Okarda, (2017) on the low uptake and implementation. This is possibly due to incomprehension and the MSPO certification process approach. Smallholders may will undergo the MSPO certification process in the future, or those smallholders who are already accredited will remain accredited in the next annual surveillance audits. MSPO certification success and sustainability depend on relationship building, trust, shared values and acceptance.

\section{Acknowledgements}

This paper would not have been possible without the continued support of the people around us. Researchers want to thank our families for their confidence and support during our Universiti Malaysia Sabah journey. However, the researchers express our gratitude to the readers for their helpful feedback and valuable comments. Thanks to Universiti Malaysia Sabah for allowing the researchers to understand and develop our academic knowledge. Researchers' findings and assumptions are not necessarily those of MSPO certifiers. 


\section{Reference}

Aaltonen, K., Jaakko, K., \& Tuomas, O. (2008). Stakeholder Salience in Global Projects. International Journal of Project Management, 26(5), 509-516.

Abazue, C. M., Er, A. C., Ferdous Alam, A. S. A., \& Begum, H. (2015). Oil Palm Smallholders and Its Sustainability Practices in Malaysia. Mediterranean Journal of Social Sciences, 6(6), 482-488.

Abdullah, R. (2013). Technical Efficiency of Independent Oil Palm Smallholders (ISH) in Peninsular Malaysia with Respect to Fertiliser and Land Size. Oil Palm Industry Economic Journal, 13(2).

Albanya, A., \& Er, A. C. (2018). Social Responsibility of Oil Palm Plantations Among Smallholders in Lahad Datu, Sabah. Journal of Fundamental and Applied Science, 10(3S), 369-382.

Alexander, S. M., Andrachuk, M., \& Armitage, D. (2016). Navigating Governance Networks for Community-based Conservation. Frontiers in Ecology and the Environment, 14(3), $155-164$.

Ang, A. (2017). Issues and Challenges in MSPO Certification. In Sirim QAS International.

Ansell, C., \& Gash, A. (2008). Collaborative Governance in Theory and Practice. Journal of Public Administration Research and Theory, 18(4), 543-571.

Azima, A. M., Choy, E. A., \& Lyndon, N. (2018). Oil Palm Smallholders in Sabah: The Institution Constraints of Innovation. International Information Institute (Tokyo). Information, 21(6), 1677-1684.

Bakke, S. (2019). The Significance of Palm Oil and its Opportunities in Pakistan. Palm Oil Trade Fair and Seminar (POTS), India 2019.

Barry, M., Cashore, B., Clay, J., Fernandez, M., Lebel, L., Lyon, T., ... Kennedy, T. (2012). Toward sustainability: The Roles and Limitations of Certification. In RESOLVE Washington $D C$.

Begum, H., Siwar, C., Alam, A. S. A. F., Choy, E. A., Ishak, S., \& Alam, L. (2018). Enhancing Sustainability Amongst Oil Palm Smallholders in Malaysia. International Journal of Agricultural Resources, Governance and Ecology, 14(1), 62-79.

Bek-Nielsen, C. (2019). RSPO Should Not Become Elitist Certification. The Star Online, pp. 9-12.

Bernama. (2019). Smallholders Look to Other Buyers for Their Palm Oil. The Star Online, pp. 7-9.

Brandi, C. A. (2017). Sustainability Standards and Sustainable Development - Synergies and Trade-Offs of Transnational Governance. Sustainable Development, 25(1), 25-34.

Chin, S. C. (2019). Adding Value Through MSPO to Benefit Smallholders in the Long Term. The Star Online, pp. 1-5.

Corley, R. H. . (2018). Does the RSPO Have a Future? The Star Online, 1-6.

Donaldson, T., \& Preston, L. E. (1995). The Stakeholder Theory of the Corporation: Concepts, Evidence, and Implications. Academy of Management, 20(1), 65-91. 
Edelenbos, J., \& van Meerkerk, I. (2018). Finding Common Ground in Urban Governance Networks: What are its Facilitating Factors? Journal of Environmental Planning and Management, 61(12), 2094-2110.

Emerson, K., Nabatchi, T., \& Balogh, S. (2012). An Integrative Framework for Collaborative Governance. Journal of Public Administration Research and Theory, 22(1), 1-29.

Gallemore, C., \& Jespersen, K. (2019). Offsetting, Insetting, or Both? Current Trends in Sustainable Palm Oil Certification. Sustainability (Switzerland), 11(19), 1-15.

Gianto, B. (2019). Palm Oil Watchdog to Create Separate Standards for Smallholders Indonesia Director. The Star Online, pp. 5-7.

Greenpeace, I. (2015). Under Fire. Greenpeace.

Hancock, D. R., \& Algozzine, B. (2006). Doing Case Study Research: A Practical Guide for Beginning Researchers. In Teachers College Press (Vol. 53).

Harrison, J. S., \& Wicks, A. C. (2019). Harmful Stakeholder Strategies. Journal of Business Ethics.

Haward, M., Jabour, J., \& McDonald, J. (2013). Small Fish in a Big Pond: Lessons from the Abel Tasman Controversy. Australian Journal of Maritime \& Ocean Affairs, 5(1), 22 27.

Hidayat, N. K., Offermans, A., \& Glasbergen, P. (2018). Sustainable Palm Oil as a Public Responsibility? On the Governance Capacity of Indonesian Standard for Sustainable Palm Oil (ISPO). Agriculture and Human Values, 35(1), 223-242.

Jones, T. M., \& Wicks, A. C. (1999). Theory Convergent. Academy of Management Review, 24(2), 206-221.

Jopke, P., \& Shconeveld, G. (2018). Corporate Commitments to Zero Deforestation. Center for International Forestry Research.

Kok, T. (2019). MSPO Certification Enables Palm Oil to Fetch Higher Price. MalaysiaKini.

Kumaran, S. (2018). The Dynamics of Malaysian Sustainable Palm Oil (MSPO) and its Implementation. In Malaysia Sustainable Palm Oil.

Kuntom, A., \& Carotino. (2014). Malaysian Sustainable Palm Oil. JC Chang Group of Companies, (60), 1-4.

Lee, J. S. H., Rist, L., Obidzinski, K., Ghazoul, J., \& Koh, L. P. (2011). No Farmer Left Behind in Sustainable Biofuel Production. Biological Conservation, 144(10), 2512 2516.

Ling, S. (2019). Govt to Maintain Target of 100\% MSPO Certification by Year-end. The Star Online, pp. 9-11.

Macdonald, K. (2020). Private Sustainability Standards as Tools for Empowering Southern Pro-regulatory Coalitions? Collaboration, Conflict and the Pursuit of Sustainable Palm Oil. Ecological Economics, 167(June).

Macdonald, K., \& Balaton-Chrimes, S. (2016). A Review of the Complaints System of the Roundtable on Sustainable Palm Oil. In Corporate Accountability Research (Vol. 15). 
Meijaard, E., \& Sheil, D. (2019). The Moral Minefield of Ethical Oil Palm and Sustainable Development. Frontiers in Forests and Global Change, 2(May).

MIDF, R. (2019). MIDF Maintains 'negative' Call on Plantation Industry on Set of Challenges. Malay Mail, pp. 9-12.

Miles, S. (2017). "Stakeholder Theory Classification, Definitions and Essential Contestability", Stakeholder Management. Business \& Society 360, 1, 21-47.

Mitchell, R. K., Agle, B. R., \& Wood, D. J. (1997). Toward a Theory of Stakeholder Identification and Salience: Defining the Principle of Who and What Really Counts. Academy of Management Review, 22(4), 853-886.

Muir, B. M. (1994). Trust in Automation: Part I. Theoretical Issues in the Study of Trust and Human Intervention in Automated Systems. Ergonomics, 37(11), 1905-1922.

Mukherjee, I., \& Sovacool, B. K. (2014). Palm Oil-based Biofuels and Sustainability in Southeast Asia: A Review of Indonesia, Malaysia, and Thailand. Renewable and Sustainable Energy Reviews, 37, 1-12.

Olsen, T. D. (2017). Political Stakeholder Theory: The State, Legitimacy, and the Ethics of Microfinance in Emerging Economies. Business Ethics Quarterly, 27(1), 71-98.

Pacheco, P., Gnych, S., Dermawan, A., Komarudin, H., \& Okarda, B. (2017). The Palm Oil Global Value Chain. Implications for Economic Growth and Social and Environmental Sustainability. Center for International Forestry Research.

Parasuraman, R., \& Riley, V. (1997). Humans and Automation: Use, Misuse, Disuse, Abuse. Human Factors, 39(2), 230-253.

Parsons, R., \& Moffat, K. (2014). Constructing the Meaning of Social Licence. Social Epistemology, 28(3-4), 340-363.

Pfeffer, J., \& Salancik, G. R. (1978). The External Control of Organizations. New York: Harper \& Row, 309-311.

Pirker, J., Mosnier, A., Kraxner, F., Havlík, P., \& Obersteiner, M. (2016). What are the Limits to Oil Palm Expansion? Global Environmental Change.

Rahgu, A. (2019). World Has Loads of Sustainable Palm Oil; Just No One Buys It. Bloomberg, 1-7. Retrieved from https://www.bloomberg.com/news/articles/2019-0113/world-has-loads-of-sustainable-palm-oil-just-no-one-wants-it

Rott, P. (2019). Certification - Trust , Accountability , Liability. In Springer International Publishing.

Rowley, T. J. (2017). The Power of and in Stakeholder Networks. Business \& Society 360, 1, $101-122$.

RSPO. (2008). Fact Sheet: Membership. RSPO.

Schaefer, K. E., Chen, J. Y. C., Szalma, J. L., \& Hancock, P. A. (2016). A Meta-Analysis of Factors Influencing the Development of Trust in Automation: Implications for Understanding Autonomy in Future Systems. Human Factors, 58(3), 377-400.

Schepel, K. (2005). The Constitution of Private Governance. Product Standards in the Regulation of Integrating Markets. Hart Publishing. 
Schouten, G., \& Glasbergen, P. (2011). Creating Legitimacy in Global Private Governance: The Case of the Roundtable on Sustainable Palm Oil. Ecological Economics, 70(11), 1891-1899.

Simeh, A., \& Tengku Ahmad, T. M. A. (2001). The Case Study on the Malaysian Palm Oil. Regional Workshop on Commodity Export Diversification and Poverty Reduction in South and South-East Asia.

TheStar. (2019). Call to Defer implementing MSPO. The Star Online, pp. 1-2.

Trade, I. (2019). Malaysia Urges EU to Recognise MSPO Certication. New Straits Times, pp. $1-5$.

Umesha, S., Manukumar, H. M. G., \& Chandrasekhar, B. (2017). Sustainable agriculture and food security. In Biotechnology for Sustainable Agriculture: Emerging Approaches and Strategies (pp. 67-92). https://doi.org/10.1016/B978-0-12-812160-3.00003-9

UN. (2019). Growing at a Slower Pace, World Population is Expected to Reach 9.7 Billion In 2050 and Could Peak at Nearly 11 Billion Around 2100: UN Report. Communications, United Nations Department of Global, (June), 1-3.

UNWCED. (1987). Our Common Future. In Oxford University Press (Vol. 29).

Vijayakumaran, S. A., Rahim, S. A., Ahmi, A., Rahman, N. A. A., \& Mazlan, A. U. (2020). Factors Influencing Sustainable Supplier Selection: Evidence from Palm Oil Refining and Oleochemical Manufacturing Industry. International Journal of Supply Chain Management, 9(1), 437-446.

Vince, J., \& Haward, M. (2017). Hybrid Governance of Aquaculture: Opportunities and Challenges. Journal of Environmental Management, 201, 138-144.

Yin, R. K. (2018). Case Study Research and Applications: Design and Methods. In SAGE Publications Ltd (6th ed., p. 509).

Zulhusni, A., Nordin, A., \& Ahmad, S. M. (2017). An Economic Study on Technical Efficiency Among Independent Oil Palm Smallholders in Sabah and Sarawak. Oil Palm Industry Economic Journal, 17(1), 16-31. 